\title{
東京特別区における屋上・壁面緑化助成の運用実態 \\ Investigation on the Incentive Programs for Green Roofs and Walls in Special Wards of Tokyo
}

熊倉 永子* 岩永 亮輔* 須永 修通*

Eiko KUMAKURA Ryousuke IWANAGA Nobuyuki SUNAGA

\begin{abstract}
Attractive buildings with green roofs and walls in urban areas are currently expected to increase in number worldwide. Although many wards in Tokyo participate in an incentive program to propagate green roofs and walls, information regarding subsidized greenery buildings, including greenery areas, types, and money spent on each building, remain unclear in many wards. In response, we conducted a questionnaire survey in each ward on the achievements and publicity activities of the incentive program in the special wards of Tokyo. The results were as follows: 1) The number of subsidized greenery buildings have declined over the past 5 years in the 17 wards, with decrease in the budget amount in 10 of those wards. 2) A comparison among the incentive programs of the city center, the sub-center, and other areas revealed that the program of the city center has promoted huge areas of greenery. 3) The ratio of budget execution of wards that have more detail condition setting for the budget amount, such as building types and soil thickness, were higher than that of the other wards. Therefore, we propose an improvement in the incentive programs in terms of increasing applications and expanding greenery areas within each ward.
\end{abstract}

Keywords: Green roof, Green wall, The special words of Tokyo, Incentive program, Questionnaire キーワード：屋上緑化，壁面緑化，東京特別区，助成制度，アンケート

\section{1. 研究の背景と目的}

屋上緑化や壁面緑化は，都市における自然の回復や美しい景観 形成, ヒートアイランド現象の緩和などを目的とし，国内外で積 極的に取り組まれている 1)-5)。東京都における屋上・壁面緑化は, 高密化する都心部で今後更に増加していくことが期待されており, 「東京における自然の保護と回復に関する条例」による屋上緑化 などの建築物上への緑化義務制度 6)や，各区が行う屋上・壁面緑 化助成制度などにより推進されている。その結果，国交省の平成 27 年全国屋上・壁面緑化施工実績調査では, 屋上・壁面緑化の施 工面積は東京都が最も多く，全国の約 4 割である 1)。

その一方で，東京特別区における屋上緑化の実態に関する既往 研究では，様々な問題等が指摘されている。例えば金ら 7)は，緑 化義務制度により創出され 10 年が経過した屋上緑化施設の調査 を行い，老朽や破損により使用不可となっている施設や，景観を 向上させる手法としての利用が可能でも利用されていない事例が あるなど，緑地の積極的な活用方法の提案が必要であることを述 べている。中林ら ${ }^{8)}$ は, 学校・病院の屋上緑化に着目し, 竣工後 の維持管理実態を調査している。緑化義務制度により緑地を整備 した学校では，使われ方が十分に議論されないまま計画され，結 果的に緑地が荒れる事例もある一方，緑化義務制度によらずに自 ら計画・整備した学校では持続性が高く，積極的に利用されてい ることが述べられている。しかし，このような観点から緑化助成 制度に関して検討した事例は少なく, 公開されている情報も限ら れている9)。

そこで本研究では，東京特別区を対象に，緑化義務制度によら ない屋上・壁面緑化助成制度によって創出された緑地とその制度 の実態に着目し，担当者へのアンケート・ヒアリング調査から， 区ごとの助成内容・実績の差を明らかにし，その要因などを考察 する。また, 考察結果をもとに, 現行助成制度の課題を抽出し, 申請数の増加及び緑地面積の拡大の観点から，各区の特色にあつ た助成内容・方策について検討・提案することを目的とする。
表-1 各区の緑化助成対象箇所（2016 年度）

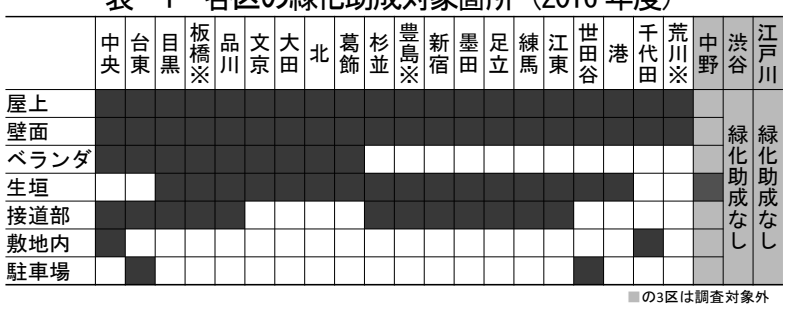

表－2 屋上・壁面緑化助成に関する各区への調査項目

\begin{tabular}{|c|c|c|c|c|}
\hline 項目 & 屋上・壁面緑化助成制度に関する質問内容 & 回答方法 & $\begin{array}{l}\text { 回答 } \\
\text { 区数 }\end{array}$ & $\begin{array}{l}\text { データ } \\
\text { 保持 } \\
\text { 区数 }\end{array}$ \\
\hline \multirow{3}{*}{$\begin{array}{l}\text { 助成の目 } \\
\text { 的/金額/ } \\
\text { 条件など }\end{array}$} & 助成金額・条件の設定方法 & 自由記述 & 15 & 12 \\
\hline & 現行助成設定茖 & 自由記述 & 15 & 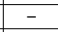 \\
\hline & 過去の助成制度 & $\begin{array}{l}\text { 年度·名称・内 } \\
\text { 容を記述 }\end{array}$ & 12 & 10 \\
\hline \multirow{4}{*}{ 運営 } & 助成制度の目標設定 & 自由記述 & 17 & 12 \\
\hline & 他の緑1 & 自由記述 & 15 & - \\
\hline & 緑化以外の助成制度との関連性 & 自由記述 & 14 & - \\
\hline & 緑化助成担当者数 & 人数を記述 & 15 & 15 \\
\hline \multirow{6}{*}{$\begin{array}{c}\text { 過去 } 5 \text { 年 } \sigma \\
\text { 助成対象 } \\
\text { 物件 }\end{array}$} & 建物用途 & 複数から選択 & 15 & 17 \\
\hline & 住所 & 自由記述 & 10 & 17 \\
\hline & 緑化箇所（屋上・壁面・地上） & 複数から選択 & 17 & 17 \\
\hline & 緑化形態（芝・低木·中高木·その他） & 複数から選択 & 13 & 15 \\
\hline & 敷地面積 & 数値を記述 & 5 & 0 \\
\hline & 緑化面積 & 数值を記述 & 17 & 17 \\
\hline \multirow{6}{*}{$\begin{array}{l}\text { 過去5年の } \\
\text { 助成実績 }\end{array}$} & 年度ごとの助成件数・面積・金額 & 数値を記述 & 17 & 17 \\
\hline & 助成地の緑被咅 & 数値を記述 & 14 & 0 \\
\hline & 区全体の緑被率の変化 & 数値を記述 & 14 & 17 \\
\hline & 冒検証の有無とその方法 & $\begin{array}{l}\text { 有無の選択、自 } \\
\text { 由記述 }\end{array}$ & 15 & 0 \\
\hline & 緑化による温熱環境効果の確認の有無 & $\begin{array}{l}\text { 有無の選択、自 } \\
\text { 由記述 }\end{array}$ & 15 & 0 \\
\hline & 申請者の意見（満足度や感想） & 自由記述 & 10 & 0 \\
\hline \multirow{3}{*}{$\begin{array}{l}\text { 維持・管 } \\
\text { 理段階 }\end{array}$} & クの有無とその方法 & $\begin{array}{l}\text { 有無の選択、自 } \\
\text { 由記述 }\end{array}$ & 15 & 7 \\
\hline & 維持・管理段階の現地調査や助成の有無 & $\begin{array}{l}\text { 有無の選択、自 } \\
\text { 由記述 }\end{array}$ & 15 & 15 \\
\hline & 維持・管理費についての見積もり & 自由 & 7 & 0 \\
\hline \multirow{4}{*}{$\begin{array}{l}\text { 広報・PR } \\
\text { 活動 }\end{array}$} & 広報活動の方法・頻度・変遷 & \begin{tabular}{|l|} 
複数から選択、 \\
年/度/内容を記述
\end{tabular} & 17 & 16 \\
\hline & 区の広報活動（イベントなど） & 自由記述 & 17 & 10 \\
\hline & 現行の広報 & 自由言 & 15 & - \\
\hline & 申請者 & & 11 & 0 \\
\hline
\end{tabular}

*首都大学東京都市環境科学研究科建築学域 


\section{2. 東京 23 区の屋上・壁面緑化助成制度の有無と調査方法}

2016 年度の各区のホームページから, 屋上・壁面緑化助成制度 の有無を調べた。中央区や台東区では，屋上・壁面緑化と地上部 の緑化を分けずに「緑化助成制度(中央区)」「台東区民間施設緑化 推進助成金(台東区)」として運用していたことから，他の区につ いても全ての緑化助成制度を調べ 12)-34), 表一1 に整理した。2011 ～2015 年度の屋上・壁面を含む緑化助成の実績について，2016 年 8 月〜 12 月に, 表一 2 に示寸 6 項目の調査をした。方法は, 各 区のホームページの閲覧，緑化助成担当部署への電話・訪問での 個別ヒアリング，メール・FAXによるアンケート用紙への記入で ある。アンケート用紙は 20 区に送り 17 区から回答を得た。訪問 での個別ヒアリングは 12 区で行った。

緑化助成後の緑化対象地の実態調査は，助成後 1 5 年後の Google Earth の航空写真と Google Map のストリートビューの 画像により，目視で判断をした。

\section{3. 屋上・壁面緑化助成制度の助成実績}

\section{（1）屋上·壁面緑化助成実績の経年変化}

図一 1 に, 回答が得られた全 17 区の 2011〜2015 年度の屋上・ 壁面緑化助成件数・面積・金額の年推移を示寸。今後, 全 17 区 を，都心区 $(\mathrm{A} \sim \mathrm{C})$ と副都心区 $(\mathrm{D} \sim \mathrm{H})$, その他の区 $\left.(\mathrm{J} \sim \mathrm{Q})^{32}\right)$ に分 けて考察する。

図-1(1)の件数の推移を見ると，多くの区で年々減少する傾向 が見られ，2014 年，2015 年は 14 区で 5 件以下である。屋上・ 壁面緑化に使用される制度や対象物件の抽出方法は異なるが，全 国を対象とした国土交通省平成 27 年の全国屋上・壁面緑化施工 実績調査 1)で報告されている屋上・壁面緑化の施工件数も，同様 に $\mathrm{H} 23$ 年から 27 年にかけて減少傾向にある。次に, 図一1(2)の 1 件あたりの面積を見ると，年による変化はあまり見られない。 都心区と L区では, いずれの年度でも他の区に比べて面積が広い。 副都心・その他の区では, 2012 年度は全体的に $20 \mathrm{~m}^{2}$ 前後の緑地 面積が多かったが，その後は $30 \mathrm{~m}^{2}$ 程度以下の面積でばらついて いる。図一1(3)の 1 件あたりの金額も，都心区と L 区はいずれの 年度でも他の区に比べて高く $\mathrm{A}$ 区と C 区は上昇傾向にあり, 近 年はより質の高い緑地が形成されている可能性がある。副都心・ その他の区では，年変化の顕著な傾向は見られない。

\section{（2）屋上・壁面緑化助成予算と執行率の経年変化}

次に, 屋上・壁面緑化助成予算額の年変化を図- 2 に示す。 3 区では 5 年間の予算額が変化せず, 10 区で年々金額が縮小傾向に ある。図-3 に示寸屋上・壁面緑化助成予算の執行率の年変化を 見ると，多くの区で $40 \%$ 以下の年が多い。特に, E・P・Q・K 区では年々減少傾向にあることも分かる。B 区のヒアリングの結 果からは, 年度予算の決定には前年度の予算使用実績を参考にし ているとの回答があったことから，執行率の低さが年度予算の低 下に影響している区もあると言える。 B・D・I・L 区は執行率が $50 \%$ 以上とな年が数年あるが, 図一 2 の予算額は減少している。

\section{（3）屋上·壁面緑化助成制度の比較}

表一 3 に 2016 年度の各区の要綱とヒアリング・アンケート調 查から得た情報を元に，屋上・壁面緑化助成制度を比較した。な お，屋上化助成の開始年については，既往研究 37)も参考にした。 都心区の屋上緑化助成では他の区に比べ上限額が高く設定されて おり，より質の高い緑地や，面積が広い緑地の創出が可能と言え る。その中でも B 区では, 家庭菜園も相談可としていることや, 住宅系建物に対する設定額が 17 区中最も高いこと，屋上と壁面 緑化を合わせた申請が可能であること，自然保護条例による屋上 緑化義務の対象となる緑地にも助成金が使用できることなど, 様々なタイプの屋上緑化を対象にしていることが分かる。一方, 副都心区では，上限額が 30〜40 万円と区による差は小さい。ま

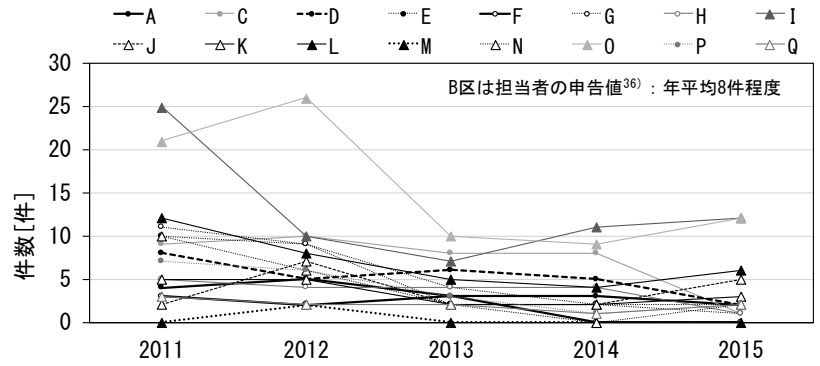

（1）屋上 - 壁面緑化助成件数の年変化 $(\mathrm{N}=17)$

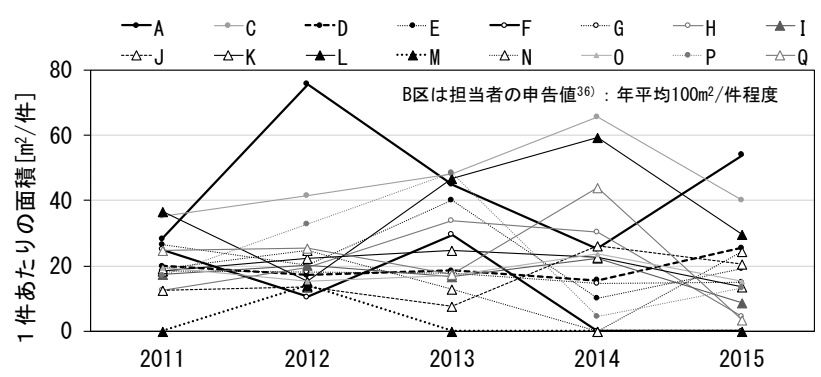

（2） 1 件あたりの屋上 ·壁面緑化面積の年変化 $(\mathrm{N}=17)$

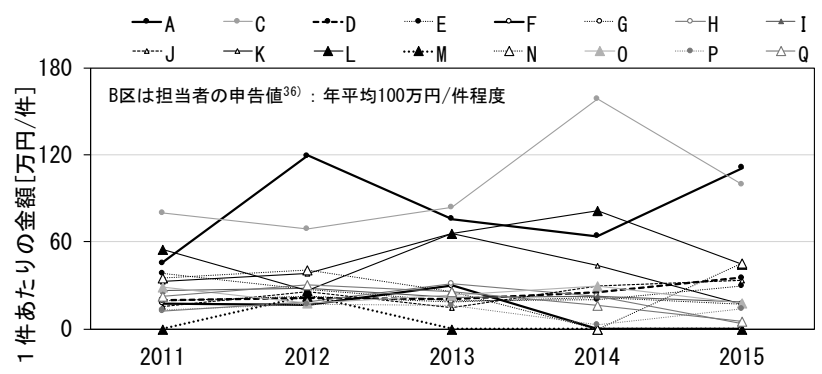

（3） 1 件あたりの屋上 - 壁面緑化助成金額の年変化 $(\mathrm{N}=17)$ 図-1 屋上 - 壁面緑化助成件数/面積/金額の年変化

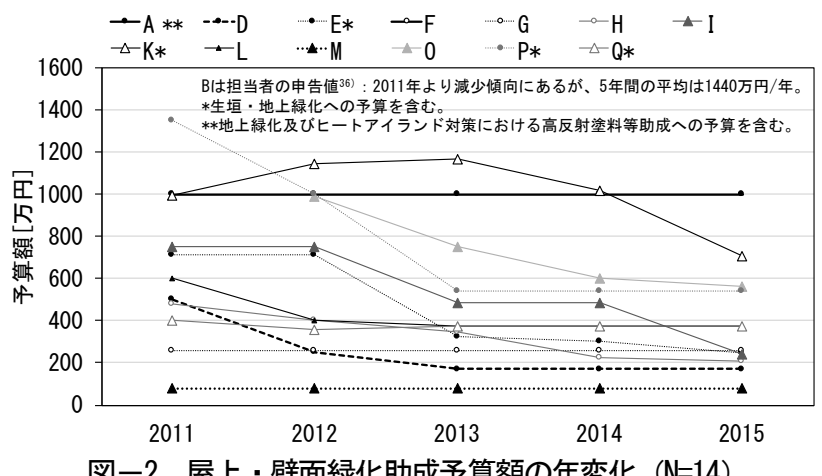

図一2 屋上・壁面緑化助成予算額の年変化 $(\mathrm{N}=14)$

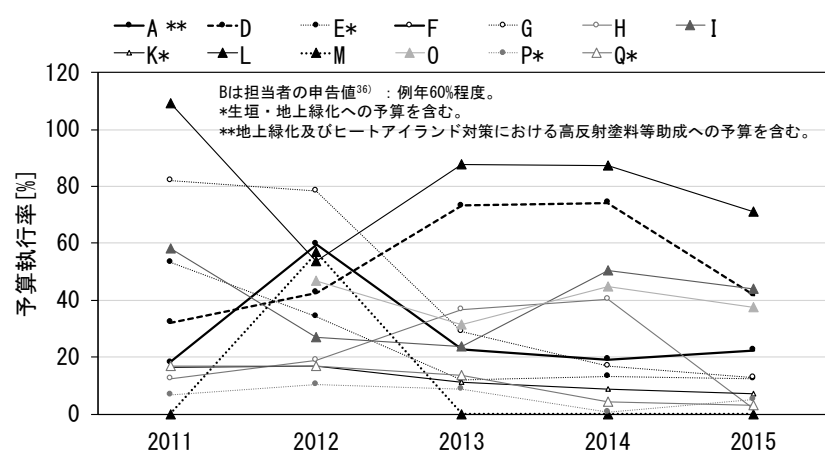

図-3 屋上 - 壁面緑化助成予算執行率の年変化 $(\mathrm{N}=14)$ 
た，他の区分に比べて上限額が低い。D，F，G 区の設定額は土 厚により助成金額を決めており, 屋上緑化のタイプによって助成 金額が変わる制度となっている。また，その他の区では，設定額 の b は他の区分と同様に $1 / 2$ の金額が助成されるが，a の単位面 積あたりの助成金額は，I・L 区を除き 2 万円以下である。 I ・ L ・ $\mathrm{O}$ 区では土厚や緑化タイプ, 建物用途によって金額が変わるため, 助成する緑化内容の詳細を確認していると考えられる。上限額を みると, 半数以上の区で壁面緑化と合わせた合計額が設定されて おり,いずれの区も屋上緑化と壁面緑化の割合は問われていない。

壁面緑化は，屋上緑化に比へ，区分別に設定額の傾向は見られ ない。上限額は，K区が最も高く 80 万円， D 区が最も低い 10 万 円である。I区では, 壁面緑化タイプ別に助成額を設定しており， 屋上緑化と同様に，助成する壁面緑化の内容を詳細に判断してい ると言える。ヒアリング調査より，緑化基盤の技術向上に伴い対 象とする壁面緑化のタイプを広げることを検討している区や，灌 水設備を義務付ける区もあった。 $\mathrm{J} \cdot \mathrm{K}$ 区では総額が各々 5,000 円 以下，10,000 円以下の場合は全額助成されるため, 登はん器具を 用いない場合や，安価な金網などで植物を誘引する場合などは， 申請者の負担が小さいと言える。

全ての区分を通じて，緑化義務制度の対象建物に対し，屋上緑 化義務面積を超過する屋上緑化面積に対しても助成金が使用でき る場合があるが，助成金と義務の担当部署の同/異や，屋上緑化助 成開始年とも特に関連はない。図一 2 より年度の予算執行率が $40 \%$ 以上の年が数年ある B・D・G・I・L・O 区では，建物用途 や土厚によって助成額の条件を詳細に設定している。

\section{4. 屋上・壁面緑化の助成先の比較}

\section{(1) 建物用途の比較}

図－4に 2011〜2015 年度で屋上・壁面緑化助成の対象となっ た建物用途別の助成件数の合計を示寸。都心区では，戸建住宅一 の助成はなく，オフィスと集合住宅が占める。副都心区では，戸 建住宅が 61.1〜 75.0\%，オフィスが 14.8～27.8\%である。その他 の区では，戸建・集合住宅が $90 \%$ 以上を占める。

\section{（2） 1 件あたりの緑化面積・件数 ·金額の傾向}

図一 5 に, 助成件数と $1 \mathrm{~m}^{2}$ あたりの助成金額および 1 件あたり の緑化面積について，2011～2015 年の年度平均值を示す。

都心区の A・C 区は 1 件あたりの金額が 1.8 2.1 万円 $/ \mathrm{m}^{2}$ と高 い。B区は，A・C 区に比べて 1件あたりの面積が広い。これは， $\mathrm{B}$ 区では緑化義務制度の対象建物における屋上緑地一も助成金の 使用が可能であることから，義務対象建物からの申請を認めてい ない C 区に比べて, 助成対象亡なる建物や屋上緑地の規模が大き くなる傾向があるためと考えられる。A・C 区は 1 件あたりの緑 化面積は $50 \mathrm{~m}^{2}$ 程度となるが, B 区に比べ，予算をかけた緑化が， 緑化義務制度により創出される屋上緑地とは別に，新たに創出さ れていると言える。副都心区では, $20 \mathrm{~m}^{2}$ 程度, 1.2 万円 $/ \mathrm{m}^{2}$ 前後 の助成を受ける緑化が多い。年間 3 件以上の D $\mathrm{E} \cdot \mathrm{G} \cdot \mathrm{H}$ 区は, 建物用途が似た傾向にあるが， E 区の金額が高く, H 区は低い。 H 区は，区の設定額の上限が 1 万円 $/ \mathrm{m}^{2}$ で最も低いことが影響して いる可能性がある。その他の区では，緑化面積は 15～35m² と区 によってばらつきがあるが, 助成件数が多い $\mathrm{I} \cdot \mathrm{L} \cdot \mathrm{O}$ 区をみると， 金額は $1.3 \sim 1.5$ 万円 $/ \mathrm{m}^{2}$ と同程度である。 I・O 区は L 区に比心゙ て緑化件数は多く, 面積は小さい。助成件数が 2 4 件の区をみ ると, $\mathrm{P}$ 区では面積は広いが金額は 0.6 万円 $/ \mathrm{m}^{2}$ と最も低く, $\mathrm{K}$ ・ $\mathrm{N}$ 区では 1.8 万円 $/ \mathrm{m}^{2}$ であり，これは，表一 3 の各区の助成設定額 が影響していると思われる。なお，L・O 区は他の区に比べて申 請数や予算執行率が比較的高く, 都心 B 区之同様に緑化義務制度 による屋上緑化義務分への使用が影響している可能性も示唆され たが，個別ヒアリング調査を行った結果，義務対象物件からの申
表－3 各区の屋上 - 壁面緑化助成制度の比較（2016 年度）

\begin{tabular}{|c|c|c|c|c|c|c|c|c|c|c|}
\hline & \multicolumn{3}{|c|}{ 屋上緑化 } & \multicolumn{3}{|c|}{ 壁面緑化 } & \multirow{3}{*}{\begin{tabular}{|l|} 
屋上緑化 \\
䄱分へ \\
の使用 \\
\end{tabular}} & \multirow{3}{*}{$\begin{array}{l}\text { 屋上緑化茅と助成の } \\
\text { 担当部署 } \\
\end{array}$} & \multirow{3}{*}{ 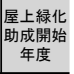 } \\
\hline & & \multicolumn{2}{|c|}{ 設定額 } & \multirow{2}{*}{$\begin{array}{c}\text { 上限額 } \\
\text { [万地 }\end{array}$} & \multicolumn{2}{|c|}{ 設定額 } & \multirow{2}{*}{$\begin{array}{c}\text { 上限額 } \\
\text { [万的 }]\end{array}$} & & & \\
\hline & & $\mathrm{a}$ [万円 $\left./ \mathrm{m}^{\prime}\right]$ & $\mathrm{b}$ [万円] & & $\mathrm{a}$ [万円 $\left./ \mathrm{m}^{*}\right]$ & $\mathrm{b}$ [万円] & & & & \\
\hline \multirow{3}{*}{ 都 } & A) & 3 & $1 / 2$ & 200 & 0.5 & \multirow{8}{*}{$\begin{array}{l}\text { 屋上緑化 } \\
\text { 之同様 }\end{array}$} & 50 & $\Delta$ & 同 & (2003) \\
\hline & & $\begin{array}{c}3 \text { (50)程度家庭菜 } \\
\text { 園も可) }\end{array}$ & $\begin{array}{l}2 / 3 \text { (住宅系) } \\
1 / 2 \text { 俳住毛系) }\end{array}$ & $200 *$ & 0.5 & & $200 *$ & O & 同 & 1994 \\
\hline & 0 & 2. 5 & $1 / 2$ & 500 & 1.5 & & 45 & $x$ & 異 & (2002) \\
\hline \multirow{5}{*}{ 副 } & $D$ & 1. 5-3(土厚による) & $1 / 2$ & $30 * *$ & 0.5 & & 10 & $x$ & 同 & 2008 \\
\hline & \multirow{4}{*}{\begin{tabular}{|l|}
$E$ \\
$F$ \\
$G$ \\
$H$ \\
\end{tabular}} & 2 (10\%程度㚼も可) & $1 / 2$ & $30 *$ & 0.5 & & 15 & $x$ & 異 & 2003 \\
\hline & & 1. 5-3(土厚による) & $1 / 2$ & 30 & 1 & & 30 & $x$ & 同 & (2003) \\
\hline & & 1-3(土厚による) & $1 / 2$ & $30 *$ & 1.5 & & $30 *$ & $\Delta$ & 同 & 2002 \\
\hline & & 1 & $1 / 2$ & 40 & 1 & & 40 & $x$ & 同 & 2003 \\
\hline & & \multicolumn{2}{|c|}{ 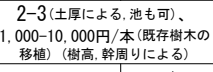 } & 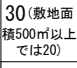 & \multicolumn{2}{|c|}{$\begin{array}{l}\text { (登はん型) } 0.2 \\
\text { (下垂) } 0.4 \\
\text { (ハネル型) } 2\end{array}$} & 30 & O & 同 & 2002 \\
\hline s & J & 2 & $1 / 2$ & 100 & 0.5 & $1 / 1$ & 20 & $x$ & 同 & (1993) \\
\hline \multirow{2}{*}{$\xi \mid \begin{array}{l}\mathrm{K} \\
\mathrm{L}\end{array}$} & & 2 & $1 / 2$ & 80 & 1 & $1 / 1$ & 80 & $\Delta$ & 異 & (2005) \\
\hline & & 2 (法人) $/ 2.5$ (個人) & $1 / 2$ & $\begin{array}{l}150 * \text { (洼) } \\
100 * \text { (個) }\end{array}$ & $\begin{array}{l}0.8 \text { (洼人) } \\
1.25 \text { (個人) }\end{array}$ & \multirow{6}{*}{$\begin{array}{l}\text { 屋上緑化 } \\
\text { と同様 }\end{array}$} & $\begin{array}{l}150 * \text { (洼) } \\
100 * \text { (個) }\end{array}$ & O & 同 & 2003 \\
\hline 他 N & $n$ & 2 & $1 / 2$ & $40 *$ & 1 & & $40 *$ & $x$ & 同 & 2006 \\
\hline ( & v & 2 & $1 / 2$ & $50 *$ & 2 & & $50 *$ & $\triangle$ & 異 & 2009 \\
\hline c & 0 & 1. 5-2（土厚はよる) & $1 / 2$ & $50 *$ & 1 & & $50 *$ & $\Delta$ & 同 & 2003 \\
\hline F & p & 1.5 & $1 / 2$ & $30 *$ & 0.5 & & $30 *$ & $\Delta$ & 同 & 2008 \\
\hline 0 & Q] & 2 & $1 / 2$ & $60 *$ & 0.75 & & $60 *$ & $x$ & 同 & 2005 \\
\hline
\end{tabular}

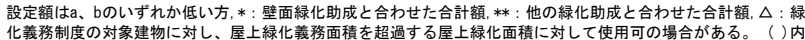
の年度は, 既往文献37)の年度を用いている。

曰内訳不明 ロ戸建住宅 ロ集合住宅 ロオフィス ロその他

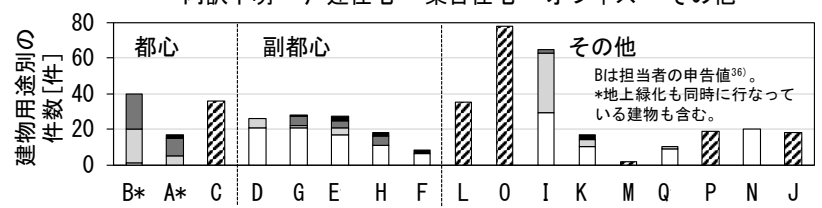

図一4 屋上・壁面緑化助成先の建物用途（2011 2015 年度合計）
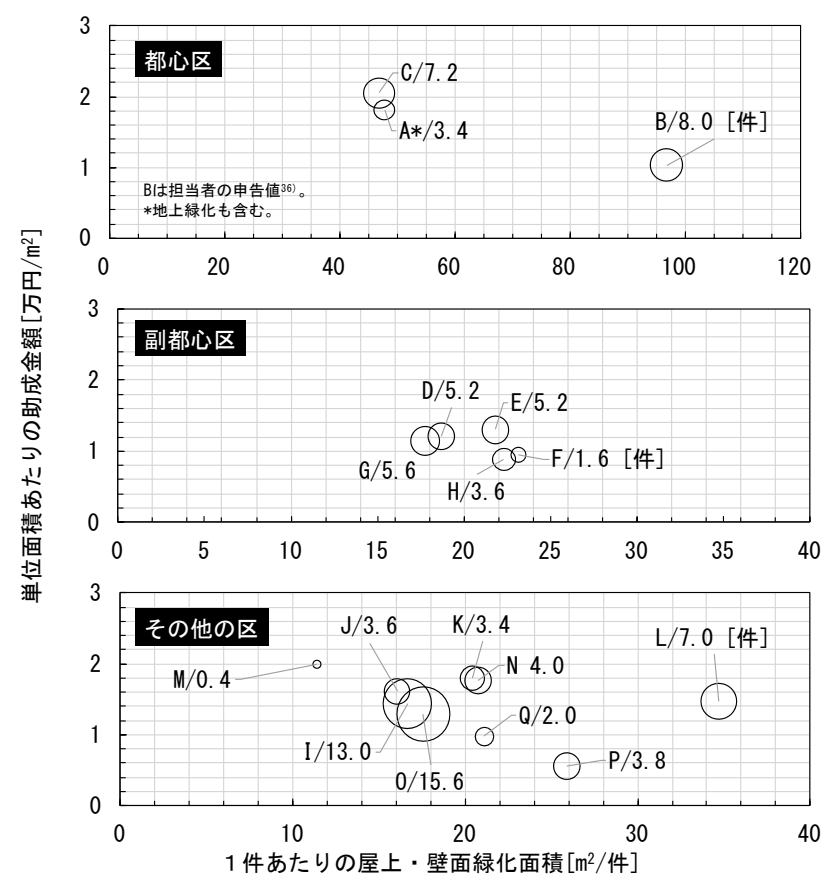

図-5 各区の助成先の面積 $\cdot$ 金額 $\cdot$ 件数の比較 （2011 2015 年度平均）

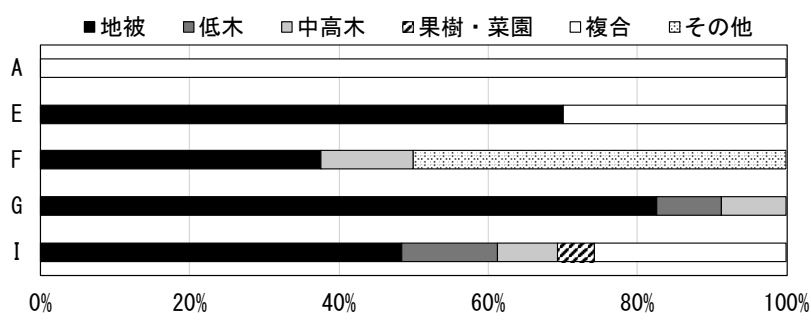

図一6 助成を受けた屋上緑化の形態（2011～2015 年度合計） 
請はほぼないとのことであった。

\section{（3）助成を受けた屋上緑化の形態の比較}

次に, 助成を受けた屋上緑化の質に関わる情報として, 緑化形 態(地被・低木・ 中高木・果樹/菜園・複合・その他)の情報が得ら れた $\mathrm{A} \cdot \mathrm{E} \cdot \mathrm{F} \cdot \mathrm{G} \cdot \mathrm{I}$ 区について図一 6 に割合を示した。これよ り，複合が含まれる割合が多いA，E，I区では，図一5の単位面 積あたりの金額が高い傾向にあることが分かる。I 区では，表-3 より様々な緑化形態を想定した助成が行われており，実際に助成 された緑地の形態も 6 区の中では最も種類が多い。図一-3の予算 執行率を見ると $50 \%$ を超える年もあることから, 様々な緑化形態 に対応することは，助成制度の利用を促進する可能性がある。

また図一5 の結果から助成先 1 件あたりの金額を計算すると,

$\mathrm{E} ・ \mathrm{I}$ 区ではそれぞれ 28 万円，24 万円となり，各区の設定上限額 の $80 \%$ 以上に達している。いずれの区も図一 3 の予算執行率を見 ると余裕があるため，これらの区では 1 件あたりの助成上限額を 上げることで，質の高い屋上緑地の件数もしくは面積を増やすこ とに繋がることが示唆される。

\section{5. 屋上·壁面緑化助成後の実態}

\section{（1）助成後の緑地の維持管理に関する申請者と自治体の役割}

植物は生長や枯调など状態が変化するため, 助成後の実態を把 握することも重要である。そこでまず，17 区の 2016 年度の緑化 助成制度の要綱, ホームページ, 緑化助成に関するパンフレット・ PDF, 緑化助成申請書の情報から, 助成後の緑地の維持管理につ いて, 申請者の責務と, 自治体による状況の調査に関寸る記載を 調べた(表一4)。その結果，申請者の維持管理責務の記載があった 区は 14 区であり，その中でも 10 区で $3 \sim 5$ 年等の具体的な年数 が記載されていた。一方, 自治体による調査の記載は 3 区であり, 緑地の維持管理段階における自治体の関わりは少なく, 申請者の 自己管理に任されている区が多いということがわかる。

\section{（2） $\mathrm{E} \cdot \mathrm{F}$ 区における助成後の屋上緑化の維持管理実態}

次に, 緑化助成後の管理状態について, 屋上緑化助成対象地の 住所が入手できた E・F 区の実態を GoogleEarth の航空写真と GoogleMap のストリートビューの画像より調査した。今回対象 とした地域での GoogleEarth, GoogleMap の画像は，E 区では 2014 年 6 月〜 2016 年 8 月, $\mathrm{F}$ 区では 2014 年 4 月〜 2015 年 11 月のものを使用した。

表一 4 において $\mathrm{E}$ 区・F 区の(A)申請者に対寸る助成後の緑地の 維持管理責務については，E 区では「2)具体的な年数の指定はな いが維持管理責務に関する文章がある」，F区は「1)具体的な年数 が指定されている(5 年)」であった。(B)自治体による助成後の緑 地の維持管理状況調査については，F 区では「3)全くない」であ り，E区では「2)具体的な指定はないが職員が調查を行う文章が ある」であったが，個別ヒアリングより，実際には行っていない とのことであった。

表一 5 に調査項目とその結果を示寸。助成後 $1 \sim 5$ 年の助成地の 使われ方や，建物の周辺の緑地などを調べた。緑地の使われ方は 植栽の鑑賞や，家庭菜園，遊び場など様々であるが，今回は， GoogleEarth と GoogleMap の画像から判断可能なものとして, ベンチやテーブル類に着目し，それらが屋上に設置されている場 合には，緑地を積極的に使用していると仮定した。また，維持管 理状態については, GoogleEarth, GoogleMap から植物の生育状 態を判断寸るには限界があるため, 対象建物の屋上面に植物と思 われる緑色状のものがある場合を屋上緑化が維持管理されている ものとした。場所によっては，解像度が高い画像が得られる時期 が秋〜冬の場合があったが，1)冬季の画像でも繁茂した緑色が確 認できたもの，2)冬枯れをした茶色でも別の季節の画像で緑色が 確認できたもの，3)Google Map のストリートビューの画像で屋
表-4 助成後の緑地の維持管理に関する申請者と自治体の役割

A) 申請者に対する助成後の緑地の維持管理責務に関する記載 $(\mathrm{N}=17)$

1) 具体的な年数が指定されている（3〜5年） 10 区

2) 具体的な年数の指定はないが維持管理責務に関する文章がある

3）全くない、その他 3区

B) 自治体による助成後の緑地の維持管理状況調査に関する記載 $(N=17)$

1) 申請者からの毎年の写真報告を 5 年間確認する

2）具体的な指定はないが職員が調査を行う文章がある

3) 全くない

表-5 $\mathrm{E} \cdot \mathrm{F}$ 区の屋上緑化助成先の調査項目と結果

\begin{tabular}{l|c|c}
\hline & $\mathrm{E} 区(\mathrm{n}=25)$ & $\mathrm{F}$ 区 $(\mathrm{n}=8)$ \\
\hline 助成籄所の緑が維持されているか & $87.0 \%$ (不明2除) & $100 \%$ \\
\hline 屋上にベンチ類などが見られたか & $47.8 \%$ (不明2除) & $0.0 \%$ (不明2除) \\
\hline 助成箇所以外の緑(花壇等を含む)が確認されたか & $70.6 \%$ (不明8除) & $50.0 \%$ (不明2除) \\
\hline 周辺 $100 \mathrm{~m}$ 以内にまとまった緑地があるか & $56.0 \%$ & $100.0 \%$ \\
\hline
\end{tabular}

上からはみ出る樹木などの緑色が確認できた場合には，緑化が維 持されているとした。いずれの画像にも植物とみられる緑色状の ものが対象屋上面にない場合は, 維持管理状態が悪いと判断した。

その結果, $\mathrm{E} \cdot \mathrm{F}$ 区では約 9 割以上の助成地で緑化が維持され ていた。 $\mathrm{E} ・ \mathrm{~F}$ 区では，助成後の自治体による維持管理状況の調 査は実質されていないことから, それらが申請者の屋上緑化の維 持管理に対する意識に与える影響は小さいと言える。また E 区で は, 屋上の緑化箇所へのベンチ類の配置が 5 割, 助成箇所以外の 玄関や庭などへの緑化が見られる事例が 7 割程度など, 緑化に積 極的に取り組んでいる傾向にあった。担当者への個別ヒアリング でも, 屋上緑化に対する意識が高い申請者が助成を受けている旨 の発言があった。一方で, 図-3 の E 区の予算執行率を見ると 2012 年度以降は $50 \%$ 未満で減少傾向にある。このことは, 自治 体と申請者の意識にギャップがあり，実際の助成先でみられたよ うな屋上緑化によって生活環境が向上するメリットを, 自治体か らも積極的に情報発信することで, 申請者を増やせる可能性があ ると言える。そのためには, 屋上緑地の具体的な使い方を促す情 報も合わせて, 助成対象者へ知らせることが重要と考えられる。

\section{6. 緑化助成における各区の PR 活動について \\ (1) 緑化助成の目的・背景の抽出}

これまで分析した全 17 区について，各区の緑化助成の背景や 目的で記載されている, 緑化の機能·効果に関寸るキーワードを, 2016 年度の区のホームページや緑化助成のパンフレットから抽 出し, 表一638)にまとめた。都市における緑化の機能・効果に関す るキーワードは, 引用文献 39), 40)をもとに整理した。その結果, 区の立地に関わらず，半数以上の区でヒートアイランド対策効果 などの「都市気象の改善効果」や，「都市景観の形成効果」などの, 広域的な緑化によって住民が間接的に得られる効果を目的として あげていた。一方で，小規模な緑地でも申請者が直接得られる効 果である，園芸療法や，樹冠や壁面緑化による局所的な日射遮蔽 による微気象の緩和等の「身近な環境の改善効果」について言及 している区は半数で, 都心区に多い。これらの効果は, 緑地の形 態や規模, 場所によって発揮される効果も異なる。

これまでの調査結果の比較にあったように，区によって申請し やすい緑地の大きさや予算が異なることから，それぞれが目指す 緑地と，それに伴って期待できる効果も具体的に示すことが必要 と考えられる。特に住宅の小規模な緑地を対象とする区では, 個 人の利益に直接的に関わる効果を知らせることが助成申請数の増 加に繋がると考えられるが，現状では例えば「省エネ・断熱」を あげている区は 4 区と少ない。また，ヒアリング調査では，バー ベキューや子供の遊び場などの家族団らん, 鄎いの場として提案 した方が助成申請に繋がりや寸いと感じるという声も聞かれた。

\section{（2）緑化助成の PR 方法の比較}

表一7 に，アンケートとヒアリング調査から得た各区の緑化助 
成に関する全ての PR 活動をまとめた。全ての区で，区報誌とホ 一ムページを媒体として PR をしていた。また，多くの区でイ心゙ ントを開催し緑化助成の PR 活動を行う事例が見られた。活動内 容は助成に関するパンフレット配布・設置が多い。緑化に関する 説明会・講習会, 苗木などの配布や販売などを行う区は 8 区あつ た。PR と助成実績の関係を見ると，都心区の A・C 区ではイ心゙ ント数の多さが助成実績に関係している可能性がある。K区もイ ベント数は多いが，区の担当者への個別ヒアリングより，その効 果は生垣助成の申請数の増加へつながっているとの回答があった。 しかし全体的には, 緑化実績と PR の種類やイベント数などの関 係性は見られなかった。

アンケート調査にて申請者の属性を聞いたところ，建築業者が 申請をしている事例が 8 区であった。 $\mathrm{A} \cdot \mathrm{B} \cdot \mathrm{D} \cdot \mathrm{E} \cdot \mathrm{G} \cdot \mathrm{N}$ 区へ の個別ヒアリングでは，建物を新築する際に，施主が建築業者か ら緑化助成制度の情報を知り, 緑化を決めて助成を申請すること が多いとの回答があった。したがって，現在行われている区民向 けの PR 活動だけでなく, 緑化関係業界に向けた PR 活動を行う ことも, 今後申請件数を増やすことにつながると言える。実際に, 各区のアンケート調査でも，区民への PR とは別に，緑化関係業 者への PR を検討したいと答えた区は 14 区中 8 区と半数以上で あり，担当者も意識していることがうかがえる。

\section{7. 現行の屋上・壁面緑化助成に対する提案}

表一7 より, 多くの区で積極的な PR 活動を行なっているにも 関わらず, 図一 3 で示したように, 緑化助成予算額の執行率が低 く，近年は予算も縮小傾向にある区も多い。そこで, 緑化助成の 運用や実績の比較を通じて, (1)申請件数を増やすための提案と (2) 助成により屋上緑化面積を拡大寸るための提案を行う。

\section{（1）屋上・壁面緑化助成の申請件数を増やすための提案}

表一7 の PR 方法の比較より $\mathrm{A} \cdot \mathrm{C} \cdot \mathrm{K}$ 区のイベントの多さと 助成制度の認知度に関係がある可能性があることや，B区への個 別ヒアリング調査から, 緑化義務対象の建物の申請に来る人に対 して, 助成制度を積極的に案内していること等, 周知活動は重要 である。特に, 緑化義務対象の建物でも条件によって申請が可能 な区は 17 区中 9 区あり，効果は高いと考えられる。

次に，申請件数が多い I・O 区の傾向より，いずれも表-3の 助成制度をみると土厚によって助成金額を変えており，担当者が 申請される緑地の詳細を確認していることが予想される。1 件あ たりの緑化面積が $18 \mathrm{~m}^{2}$ 程度と規模が小さいため, 図一 4 の I 区 の建物用途の内訳を見てわかるように，住宅用途からの申請が多 く, 図一6 の緑化の形態も菜園・果樹を含むなど多彩である。I 区では，表一6でまとめた中に，区が求める緑化のイメージとし て，「触れられるみどり」という記載があり，個人が直接的に受け る恩恵も緑化推進の背景として述べられている。さらに，個別の ヒアリング調査より，I 区では緑が多い区としてのブランド化に 向けた様々な活動が行われ，区民の意識も高いと言う。このよう な, 1 件あたりの緑化面積が小さく, 住宅用途からの申請が多い 区では，申請者や区民が緑化によるメリットを理解していること が，申請数の増加につながっていると言える。したがって，緑地 の多様な使い方やデザイン，住宅に対寸る具体的な効果など，緑 地を活用したライフスタイルの提案も区民一向けて発信すること が, 緑化意識の向上とともに緑化助成申請数の増加に役立つと考 えられる。

\section{（2）屋上・壁面緑化助成による緑化面積を拡大するための提案}

17 区中 6 区では, 緑化義務制度の対象建物にも, 屋上緑化義務 面積を超える屋上緑化面積に対して助成金が使用できる。個別の ヒアリング調査から，そのような事例を聞くことはなかったが， 今後義務と助成を併用できることが積極的に周知されれば，建物
表－6 各区の緑化助成の背景と緑地の機能・効果

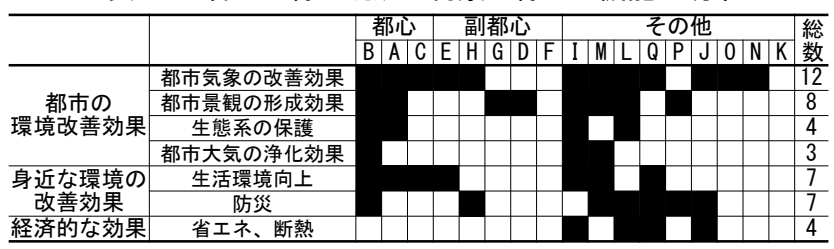

表-7 各区の緑化助成の PR 方法の比較

\begin{tabular}{|c|c|c|c|c|c|c|}
\hline & & $\begin{array}{l}\text { 区報誌 } \\
\text { [回/年 }]\end{array}$ & HP & $\begin{array}{l}\text { CATV } \\
\text { [回/年] }\end{array}$ & $\begin{array}{l}\text { イベント } \\
\text { [回/年 }]\end{array}$ & 具体的な活動内容 \\
\hline \multirow{3}{*}{ 都 心 } & A & 1 & O & 0 & 10 & $\begin{array}{l}\text { マンションにパンフレット配布, } \\
\text { 町会長会議・婦人会·商工会·マンション自治会/管理会, } \\
\text { 警察・消防所などと合同の説明会 }\end{array}$ \\
\hline & B & 1 & O & 0 & 2 & $\begin{array}{l}\text { 緑化計画と合わせて助成制度をお知らせ, } \\
\text { 花と苗木の即売会 (春・秋) }\end{array}$ \\
\hline & c & 1 & 0 & 0 & 7 & \\
\hline \multirow{5}{*}{ 副 } & D & 1 & O & 0 & 不明 & $\begin{array}{l}\text { 緑化・環境に関する区のイベント (パネルなど設置や緑化 } \\
\text { 相談など) }\end{array}$ \\
\hline & $\mathrm{E}$ & 2 & O & 0 & 1 & $\begin{array}{l}\text { 区報誌はエコガイド, 庁舎屋上にモデルガーデン, 造園業 } \\
\text { 者の紹介, エコフェスタ (パンフレット配布) }\end{array}$ \\
\hline & $\mathrm{F}$ & 不明 & 0 & 0 & 不明 & \\
\hline & G & 1 & O & 0 & 1 & $\begin{array}{l}\text { 広報誌 緑の特集(5月), 区民農園 } \\
\text { エゴル゙型など展示) }\end{array}$ \\
\hline & H & O & O & 0 & 不明 & $\begin{array}{l}\text { 区主催のイベントにてパンフレットを配布 } \\
\text { 区民向けの屋上・壁面緑化モデルの見会実施を検討中 }\end{array}$ \\
\hline \multirow{9}{*}{$\begin{array}{l}\xi \\
\text { の } \\
\text { 他 }\end{array}$} & I & $1-2$ & 0 & 0 & 0 & $\begin{array}{l}\text { 緑化計画の際に建築主にパンフ郵送 } \\
\text { 今後イベントでの周知を検討 }\end{array}$ \\
\hline & J & 1 & O & 0 & 2 & $\begin{array}{l}\text { 区報誌 環境月間(6月) } \\
\text { 区民植木市 (4月)でゴーヤの種の配布、環境展 (11月) }\end{array}$ \\
\hline & $\mathrm{K}$ & 1 & O & 0 & 30 & $\begin{array}{l}\text { 緑化のキャラクターがいる,協定地区などに苗木, 協定団 } \\
\text { 体へPR依頼, 住宅系PR誌に揭載 } \\
\text { お祭り,緑化啓発イベント, 田木配布, 募金活動, 工作教室 }\end{array}$ \\
\hline & & 1 & 0 & 0 & 1 & 緑のイベント \\
\hline & M & 1 & O & 3 & 不明 & $\begin{array}{l}\text { 他部署での事業でもチラジ配布など, CATV (6〜8月) } \\
\text { 小学生対象のスプラリー, 園芸教室、住宅デー }\end{array}$ \\
\hline & N & 1 & O & 0 & 4 & 緑のカーテン講習会, 建築系・農業系のイベント \\
\hline & 0 & 1 & O & 0 & 3 & $\begin{array}{l}\text { ガーデニングフェア, 区民祭りでのブース出展, } \\
\text { 花いっぱいコンサート, 緑のカーテン講習会, 落ち葉拾い }\end{array}$ \\
\hline & $\mathrm{P}$ & 1 & 0 & 0 & 不明 & HPI工事前工事後の写真掲載, 助成地ヘプレート設置義務 \\
\hline & Q & 不明 & O & 0 & 不明 & $\begin{array}{l}\text { 屋上緑化見本園にて業者の紹介 } \\
\text { 環境緑化フェア }(6 \text { 月)で苗木の配布 }\end{array}$ \\
\hline
\end{tabular}

1 棟あたりの屋上緑化面積の拡大が見込める。

都心区では，他の区分に比べて助成 1 件あたりの面積が大きい 傾向であったように, 集合住宅やオフィスなどの大規模な建築物 からの申請を想定した金額設定は重要である。図一4より戸建住 宅とオフィスに助成し，1 件ごとの情報がわかる副都心区の $\mathrm{E}$ ・ $\mathrm{G}$ 区で，建物用途別の助成金額，面積を比較すると，戸建住宅は 13 $18 \mathrm{~m}^{2} /$ 件程度， $1.3 \sim 1.6$ 万円 $/ \mathrm{m}^{2}$ であるが，オフィスでは， 33〜 $41 \mathrm{~m}^{2} /$ 件程度, $0.7 \sim 2$ 万円 $/ \mathrm{m}^{2}$ 程度となり, 1 件あたりの金額 は 29〜43 万円/件で，E 区は設定額の上限を超えている。したが って, 戸建住宅に比べて屋上面積が確保しやすいオフィスなどか らの申請がある区では，建物用途別に想定する屋上緑化の面積を 明確にした上で，設定額を増額することも，屋上緑化面積の拡大 へつながる。実際に， E・G区と同じ副都心区の D 区へのヒアリ ング調査からは，限られた予算の中で，大規模な緑化一助成をす ることと, 小規模で多数の緑地一助成することのバランスが難し いとの意見も聞かれた。今後, より大規模な緑地一の助成を促進 させるためには，B・L 区のように，助成条件を住宅系非住宅系 や個人法人に分けるなど, 申請建物の条件によって助成金額の設 定を工夫することも考えられる。

\section{8. まとめ}

本研究では東京特別区の 17 区に対し, 各区の担当者へのアン ケート・ヒアリング調查から, 屋上・壁面緑化助成制度の助成実 態と助成された緑地の傾向を調べた。得られた知見を以下に示す。 1)東京特別区 17 区における屋上・壁面緑化助成件数は, 2011 2015 年度にかけて減少傾向にあり，予算額については，14 区中 10 区で縮小傾向にあった。2)17 区を都心区，副都心区，その他 の区に分けて屋上・壁面緑化助成制度を比較すると, 助成設定額 や助成先の建物用途などの傾向が異なったが，全ての区分におい 
て建物用途や土厚によって助成額の条件を詳細に設定している区 ほど予算執行率が高い傾向にあった。3)データが得られた 5 区に おいて, 助成を受けた屋上緑化の形態を比較した結果, 助成金額 が高い区ほど，複合緑化の割合が多かった。4)データが得られた $\mathrm{E} \cdot \mathrm{F}$ 区の助成後の屋上緑地の管理状況を Google の画像から調査 した結果，9 割以上で緑化が確認され，助成後の自治体による維 持管理状況の調査がない場合でも，緑化が維持されていることが わかった。5)現行の屋上・壁面緑化助成制度の運営に対し，申請 件数の増加, 緑化面積の拡大の視点から, 周知活動で発信する情 報を検討すること，申請建物によって助成条件を工夫寸ること等 の改善点を提案した。

謝辞：本研究では、各区の屋上・壁面緑化助成担当者のご協力 を頂いた。記して謝意を表す。

\section{補注及び引用文献}

1)平成 27 年全国屋上・壁面緑化施工実績等調査結果 (PDF 資料) : 国土交通省都市局 公園緑地・景観課緑地環境室，2016.8.9 公開

2) Landscaping for Urban Spaces and High-Rises (LUSH) Programme: LUSH 3.0: Urban redevelopment authority ホームページ

$<$ https://www.ura.gov.sg/uol/circulars/2017/Nov/dc17-06>, 2017.11.09 更新, 2017.12.1参照 3)Skyrise Greenery Insentive Scheme 2.0: National Parks ホームページ

$<$ https://www.nparks.gov.sg/skyrisegreenery/incentive-scheme >, 更新日記載なし, 2017.12.1 参照

4) P.J. Irga, et. al (2017) : The distribution of green walls and green roofs throughout Australia: Do policy instruments influence the frequency of projects?, In Urban Forestry \& Urban Greening, 24, 164-174

5)Eco-Roof Insentive Program: City of Toronto ホームページ

$<$ https://www.toronto.ca/services-payments/water-environment/environmental-gran ts-incentives-2/green-your-roof/>, 更新日記載なし, 2017.12.1 参照

6)東京都環境局 (2017) : 緑化計画の手引き : 東京都環境局自然環境部緑環境課, 5pp 7) 金甫炫, 木下剛 (2011) : 屋上緑化施設の経年変化に関寸る調査: 日本緑化工学会誌 37(1), 179-182

8)中林俊輔, 岸井隆幸, 大沢昌玄 (2012) : 東京 23 区における屋上緑化施策に関寸る基 礎的研究一公益的施設の屋上緑化の実態加 : 都市計画論文集 47(3), 475-480 9)屋上・壁面緑化助成制度の助成実態に関する情報は，台東区や豊島区等は，区報告書 等 10),11)通じてホームページで閲覽が可能な情報があるが，例えば台東区の報告書 10)では，緑化助成の中でも，生垣，屋上，壁面などの緑化箇所別の金額の内訳が記載 されておららず, 豊島区 11 では, 年度内の総数のみが記載され, 助成先 1 件ずつの情 報は記載されていない。その他の多くの区は, ホームページ上では公開をしていない など，助成された緑地に関寸る情報は限られている。

10)台東区行政資料集 : 台東区ホームページ,

$<$ http://www.city.taito.lg.jp/index/kusei/kisoshiryou/gyoseishiryo/siryoshu/index.html >, 更新記載なし, 2016.10.1参照

11)屋上緑化等の推進 : 豊島区ホームページ,

<ttp://www.city.toshima.lg.jp/339/machizukuri/shizen/ryokuka/000879.html> 2016.3.25 更新，2016.8.5 参照

12)平成 28 年度ヒートアイランド刘策助成制度のご案内 : 千代田区環境政策課エネル ギー対策係：千代田区配布パンフレット，2016.11.10配布

13)緑化助成の手引き : 中央区環境十木部水とみどりの課緑化推進係 : 中央区配布パン フレット, 2016.11.9閲覧

14）緑化推進 : 港区ホームページ,

$<$ https://www.city.minato.tokyo.jp/kankyo-machi/kankyo/ryokuka/suishin/index.ht $\mathrm{ml}>, 2011.11 .22$ 更新, 2016.8.5 参照

15）みどりの助成制度 : 新宿区ホームページ,

$<$ http://www.city.shinjuku.lg.jp/seikatsu/index14_06.html>,2015.4.1 更新, 2016.8.5参照 16）緑化補助金制度等 : 文京区ホームページ，

$<$ http://www.city.bunkyo.lg.jp/bosai/midori/ryokuka/ikuseihozen.html>, 2014.12.4 更
新, 2016.8.5 参照

17）台東区民間施設緑化推進助成金：台東区ホームページ,

$<$ http://www.city.taito.lg.jp/index/kurashi/kankyo/jyoseiseido/ryokukasuishin.html>, 2015.4.1 更新, 2016.8.5 参照

18）墨田区の緑:墨田区ホームページ,

$<$ http://www.city.sumida.lg.jp/kurashi/kankyou_hozen/midori/index.html>,2016.8.5 参照

19)江東区みどりのまちなみ緑化助成制度 : 江東区土木部管理課 CIG 推進係 : 江東区木 ームページ掲載PDFデータ, 2016.8.5 参照

20)品川区屋上緑化等助成制度のご案内, 生垣助成のご案内 : 品川区ホームページ掲載 PDF データ, 2016.8.5 参照

21）みどりの保護の助成:目黒区ホームページ，

$<$ http://www.city.meguro.tokyo.jp/kurashi/shizen/enjo/midorihogo/index.html $>, 2013.10 .1$ 更新，2016.8.5 参照

22) 緑の保護緑化 : 大田区ホームページ,

$<$ http://www.city.ota.tokyo.jp/seikatsu/sumaimachinami/kankyou/ryoka/index.html $>$, 2016.8.5 参照

23）生垣・花壇・シンボルツリー, 屋上・壁面緑化助成 : 世田谷区ホームページ

$<$ http://www.city.setagaya.lg.jp/kurashi/102/126/418/405/d00007924.html>,2016.3.2 3 更新, 2016.8.5 参照

24）生け垣・植樹帯設置助成 : 中野区ホームページ,

<http://www.city.tokyo-nakano.lg.jp/dept/472000/d002147.html>, 2016.8.5 参照 25）杉並区屋上・壁面緑化助成金交付要綱 : 杉並区,杉並区配布資料, 2016.12 .12 26）接道部緑化助成: 杉並区ホームページ,

$<$ http://www.city.suginami.tokyo.jp/guide/machi/midori/1005060.html>, 2016.8.5 参照 27）緑化: 豊島区ホームページ,

$<$ http://www.city.toshima.lg.jp/machizukuri/shizen/ryokuka/index.html>,2016.3.25 更新, 2016.8.5 参照

28）補助・助成 : 北区ホームページ,

$<$ http://www.city.kita.tokyo.jp/jutaku/kankyo/hojo/index.html>, 2015.3.12 更 新 2016.8.5 参照

29）屋上緑化・壁面緑化の助成金制度 : 荒川区ホームページ,

$<$ https://www.city.arakawa.tokyo.jp/faq/kankyo/ekojosei/ryokukajosei.html>, 2015.4.1 更新, 2016.8.5 参照

30) 助成: 板橋区ホームページ,

$<$ http://www.city.tabashi.tokyo.jp/c_categories/index06005002.html>, 2015.3.14更新, 2016.8.5 参照

31）屋上緑化助成制度, 壁面緑化助成制度, 沿道緑化助成制度, 生け垣化助成 : 練馬区 ホームページ,PDFデータ, 2016.8.5参照

32 ) 緑化工事の助成申請受付中 (接道部, 建築物) : 足立区ホームページ, $<$ https://www.city.adachi.tokyo.jp/midori/machi/midori/joseshinse.html>, 2016.10.7 更新, 2016.8 .5 参照

33）生垣造成の補助 : 葛飾区ホームページ,

<http://www.city.katsushika.lg.jp/kurashi/1000062/1003885/1004018.html>, 2016.8.5参照

34)屋上緑化・壁面緑化の補助金をご利用ください (パンフレット) : 葛飾区環境課緑化 推進係，葛飾区配布資料，2016.12.13閲覧

35）都心とは，千代田区，中央区，港区を指寸。副都心とは東京都の定める新宿，渋 谷, 池袋, 錦糸町・亀戸, 品川・大崎, 臨海副都心を含む新宿区, 渋谷区, 豊島区, 墨田区，品川区，江東区，台東区を指寸。

36)データでの情報提供ができない区では，訪問時に閲覧した資料と，担当者から口頭 で述べられた值を元にしている。

37)高野大輔 (2010) : 屋上緑化の推進策と空間分布-東京 23 区を対象として-, 東京大 学大学院新領域創成科学研究科環境学研究系社会文化環境学専攻修士論文, $24 \mathrm{pp}$

38)本研究では屋上・壁面緑化助成制度を対象としているが，表一6では，区によって 資料が他の緑化助成制度と統一されている場合は, 屋上・壁面緑化に限らず全ての緑 化を対象としている。

39)下村孝・梅干野显・輿水肇(2005):立体緑化による環境共生:株式会社ソフトサイエン 又社, 59-60

40)財団法人都市緑化技術開発機構（2001）: NEO-GREEN SPACE DESIGN(2) : 株 式会社誠文堂新光社，27-28 